UDK: $336.711: 338.22$

DOI: 10.2478/jcbtp-2019-0004

\author{
Jasmine, M. Fouad ", Mona, E. Fayed ${ }^{* *}$, \\ Heba Talla, A. Emam ${ }^{* * *}$
}

\section{A New Insight into the Measurement of Central Bank Independence}

\begin{abstract}
The present paper attempts to expand the existing literature on Central Bank Independence (CBI) by proposing new measures for CBI. It designs two indices: one tackling the de jure $\mathrm{CBI}$ and the other assessing the de facto level of CBI. The two measures outweigh traditional measures in various aspects; first, the two indices are more comprehensive in terms of possible institutional arrangements. The de jure index incorporates several aspects related to CBI that were not previously grouped together in a unified index i.e. financial independence, limitations related to indirect credit to government, accountability and transparency. The de facto index comprises the main existing indicators for measuring actual CBI (i.e. turnover ratio, political vulnerability indicator and monetary policy reaction function) in addition to new variables, as the lender of last resort function, independence of central bank board, and financial independence that were not included in almost all previous studies. Second, the two indices allow a higher level of precision as they comprise aspects that can be objectively codified with a minimum level of subjectivity. Third, the two indices cover the same attributes of CBI to facilitate measuring the deviation between de jure and de facto level of independence for any central bank. The current paper provides a comprehensive definition and analysis of both indices to enable their replication in future studies.
\end{abstract}

Keywords: Central Bank Independence, Independence Indices, Monetary Policy, Political Economy.

JEL Classification: E52, E58
${ }^{*}$ Faculty of Economics and

Political Science, Cairo

University, Cairo, Egypt

Email:

jfouad@feps.edu.eg

${ }^{* *}$ Faculty of Economics and Political Science, Cairo University, Cairo, Egypt

Email:

monaesam@feps.edu.eg

${ }^{* * *}$ Faculty of Economics and Political Science, Cairo University, Cairo, Egypt

Email (Corresponding Author): hebatalla.atef@feps.edu.eg 


\section{Introduction}

The concept of central bank independence (CBI) and the institutional relation between central bank and government has gained momentum during the recent decades, with the dynamic acceleration by governments to delegate monetary policy to central banks (Crowe \& Meade, 2008). This move was triggered by both theoretical and empirical rationale. Theoretically, CBI is considered the primary solution for the inflationary bias of governments. Empirically, it has been argued that countries with higher CBI were able to achieve lower inflation levels and improved economic performance compared to those with lower degree of CBI (De Sousa, 2001; Kamaly \& Farrag, 2005; Bezhoska, 2017; Cargill, 2013). Accordingly, a growing part of literature tackled the issue of CBI, its measures and correlation with macroeconomic variables (like, Cukierman (1992) and Jácome (2001)).

However, CBI is a complex measure that is based on various formal and informal arrangements (Cukierman, 1992; Bezhoska, 2017). Yet, most of the empirical work that endeavored to quantify the degree of CBI focused on the formal and legal aspects of independence, without considering that the distance between theory and practice is not always short (like, Lybek (1999) and Jácome (2001)). Only a limited number of studies were devoted to measuring actual CBI through various indicators (like monetary policy reaction function, turnover ratio and political vulnerability indicator). Nevertheless, these studies were challenged for being subjective and relatively imprecise (Banaian, 2008).

In light of that, the present paper designs two indices for CBI, one covering de jure $\mathrm{CBI}$ and the other evaluating the de facto degree of $\mathrm{CBI}$. The paper is divided into two sections apart from the introduction and conclusion. The first section covers a critical assessment of previous studies measuring de jure and de facto CBI. The second section presents the newly developed measures for CBI.

\section{I) Empirical Studies on Measuring CBI}

The need to investigate the relation between CBI and macroeconomic variables prompted empirical studies to quantify the degree of CBI by constructing various indices (Banaian, 2008; Parkin, 2012). The measurement literature played a crucial role in enhancing CBI across the globe and capturing the quantitative relation between $\mathrm{CBI}$ and macroeconomic performance. Basically, measurement literature is divided in two broad categories of CBI indicators, depending on the emphasis placed on statutory provisions regulating the central bank (De jure CBI) (Issing, 2006) versus the actual independence granted to the bank (De facto 
CBI) (Hayo \& Voigt, 2008; Landström, 2013). The present section discusses in details the two measures of CBI.

\section{A. De jure Measures of $C B I$}

This approach relies on the charters of the central bank and hence reflects the statutory characteristics (Forder, 1996; Issing, 2006; Smaghi, 2008). In other words it creates an index based on the quantification of the relevant CBI criteria that are embedded in the legal documents (James, 2010).

This methodology pioneered by the work of Bade and Parkin (1982) and probably reached its full fruition by the work of Cukierman (1992) whose model has been employed in most of the recent empirical studies (Wessels, 2006; Banaian, 2008).

Bade and Parkin (1982) constructed a (1-4) scale of CBI for 12 advanced countries based on the "political independence" of the central bank (Alesina \& Summers, 1993). Political independence was defined as the ability of the central bank to select its policy objectives without interference from the government (Grilli, Masciandaro, Tabellini, Malinvaud \& Pagano, 1991; Elgie, 1998). The study concluded that a central bank that does not possess the authority of executing monetary policy cannot independently appoint its board members and vice versa (Kamaly \& Farrag, 2005). Despite the fact that this was the first study to codify legal CBI, it focused on the classification of central banks based on the political independence criteria rather than measuring the degree of CBI. Moreover, the criteria employed did not include the goal of the central bank or the price stability objective (Banaian, 2008).

Most of the subsequent work departed from Bade and Parkin's ordinal methodology into the construction of a legal index with cardinal properties (Banaian, 2008). The first was Grilli, Masciandaro and Tabellini (GMT) (1991) that designed a more comprehensive index capturing 15 variables for measuring CBI. The index was applied to 18 OECD countries (Capie, Fischer, Goodhart \& Schnadt, 1994). The index covered elements of both political and economic independence (Lybek, 1999b; Obben, 2006; Bezhoska, 2017). Political Independence was assessed through eight variables related to the central bank's governor and the board, conflict resolution between the government and the central bank, objective and formulation of monetary policy. On the other hand, economic independence was related to the ability of the central bank to use monetary policy instruments independently (Alesina \& Summers, 1993; Elgie, 1998; Kamaly \& Farrag, 2005; Arnone, Laurens, Segalotto \& Sommer, 2007). It was based on seven 
criteria covering the limitations on credit to the government, the responsibility of setting policy rates, and the banking supervision function (Jácome \& Vázquez, 2005; Hueng, 2012).

The next wave of studies was carried out by Cukierman (1992) and Cukierman, Webb, and Neyapti (CWN) (1992). They presented very comprehensive studies that covered a large set of countries including both developing and industrial countries (Kamaly \& Farrag, 2005; Parkin, 2012). The two studies distinguished between legal and actual CBI and provided means of measuring both. Regarding legal independence, the indices employed were derived from 16 criteria related to the governor, monetary policy formulation, the objectives of the central bank and the limitations on central bank lending to the government ${ }^{1}$. The only difference between the two studies is that Cukierman's index was calculated as an unweighted mean of the variables included, while the CWN's index was aggregated as a weighted mean of these variables (Banaian, 2008; Anastasiou, 2009; Dincer \& Eichengreen, 2014). The two studies have various advantages; first, they were the first to include developing countries within their scope of analysis. Second, they covered a large set of countries, allowing for cross sectional comparisons. Third, they introduced the concept of actual CBI and means to measure it. Finally, their indices were comprehensive in terms of possible institutional arrangements. In addition, the constructed indices were easily replicated in further empirical work as the studies provided a thorough guide to coding various components. Nevertheless, the two indices lack important institutional arrangements related to CBI, like financial independence, supervisory role of central bank and autonomy of the central bank's board (Ewiss, 2003; Crowe \& Meade, 2008).

Despite their valuable contributions, the above indices ignored issues related to accountability, transparency and the lender of last resort function when assessing the degree of CBI. Accordingly, Lybek (1999) developed an index for both legal CBI and accountability for 15 countries from the Baltic States, Russia and other countries of the former Soviet Union from 1995 to 1997. The independence measure was similar to those designed by GMT (1991) and CWN (1992) but in a more detailed and accurate way. Specifically, it integrated 21 variables related to policy objective, supervisory role of the central bank, foreign exchange policy and other variables. As for the accountability part, it was based on variables related to the obligation of the central bank governor to report to the parliament and government, as well as the disclosure of the central bank publications on a timely ba-

\footnotetext{
1 For further details, see Cukierman (1992), Cukierman et al. (1992), Elgie (1998), Lybek (1999b), Obben (2006), Arnone et al. (2007), Anastasiou (2009), Klomp et al. (2010), Hueng (2012) and Bezhoska (2017).
} 
sis (Lybek, 1999b; Ewiss, 2003). In addition, Jácome (2001) designed one of the comprehensive indices of legal independence and accountability, in an attempt to investigate the relation between CBI and inflation in Latin America during the 1990s. The index incorporated both political and economic independence of the central bank. The main contribution of the index was the inclusion of variables related to financial independence, lender of last resort function, accountability and transparency. Yet, the index failed to capture the supervisory role of the central bank on other banks (Kamaly \& Farrag, 2005). In a similar manner, Jácome and Vázquez (2005) designed a new measure for CBI in their study for the link between CBI and inflation in Latin America and the Caribbean during the 1990s. The new measure was called "Modified Cukierman Index (MCI)" as it was based on the structure of the CWN (1992) index. Additionally, the MCI incorporated new dimensions for CBI to capture key features of central bank reform in Latin America, as well as dimensions related to central bank accountability and transparency (Bezhoska, 2017).

Moreover, Pisha (2011) proposed a new methodology for measuring de jure CBI, whereby four indices, "called Eurozone Indices", were constructed based on the European Union and national central bank legislations in eight South-Eastern European countries and the European Central Bank (ECB). The four indices were divided into functional $\mathrm{CBI}$, institutional $\mathrm{CBI}$, personal $\mathrm{CBI}$ and financial and budgetary CBI (Ivanović, 2014). Functional independence was related to the objective of the central bank, while institutional independence was related to the central bank's freedom in the formulation and execution of monetary policy. Personal independence, on the other hand, was linked to the nomination and dismissal of the governor and the board. The final index covered the limits on government lending and the management of the central bank's budget. The value of each of the four indices was calculated as a weighted average of its components. It ranged from 1 , for the most independent central bank and 0 , for the least independent one. Weight assigned to each variable was based on the priority given to this criterion in EU legislation, which reduces the element of subjectivity in the index. However, the main criticism of these indices was the absence of a single independence measure that combines the four indices together.

Generally speaking, measures of de jure CBI were subject to various limitations both theoretically and methodologically. On the theoretical side, laws are always incomplete and do not cover every eventuality. Even if a law is relatively complete, de jure independence does not reflect the actual degree of CBI as actual practice could deviate from law (Cukierman, 1992; Cukierman, Webb \& Neyapti, 1992; Hueng, 2012; Bezhoska, 2017). The issue is even more critical when it comes to developing countries that suffer from unclear and incomplete laws, as well as 
weak rule of law (Cukierman, 2006). With all this in mind, it is quite clear that statutes do not reflect the real degree of independence (Forder, 2000; Hayo \& Hefeker, 2002; Cargill, 2013). As Forder (1996) claimed, there is no theory that says it matters what the rules says, it is only the behaviour that counts. Concerning the applied methodology, most of the available indicators of legal independence are based on some degree of arbitrariness with indices comprising different legal provisions and even the same arrangements are assigned different codes and weights across the studies (Ewiss, 2003; Berger \& de Haan, 1999; Issing, 2006; James, 2010; Parkin, 2012). This could be attributed to the lack of relevant theory guiding the construction of CBI indices in terms of the significant elements to be included, the codification system and the assignments of weights (Banaian, 2008).

\section{B. De facto Measures of $\mathrm{CBI}$}

Due to the drawbacks of the de jure measures, another school of literature recommended relying on de facto measures of independence to capture the effective degree of independence conferred on the central bank (Ewiss, 2003; Banaian, 2008; Hayo \& Voigt, 2008). De facto independence depends on various formal and informal institutional arrangements, like the central bank's ability to engage in open market operations, the existence of explicit institutional arrangement other than law that makes price stability the overriding objective of the central bank and the quality of the central bank's research department (Cukierman, 1992; De Sousa, 2001; Ivanović, 2014). Thus, it is difficult to quantify the actual degree of independence as it requires assessing both the behaviour and practice of the central bank. Yet, various indicators were introduced in literature as proxies for the actual degree of CBI.

Cukierman (1992) and CWN (1992) were the first to differentiate between legal and actual independence in their studies and designed two indicators to capture actual independence (Obben, 2006; Frankel, 2010; Parkin, 2012). The first was the rate of turnover of central bank governors (James, 2010; Hueng, 2012), which relied on the actual average terms of office of central bank governors as a proxy of practical independence ${ }^{2}$. The indicator was based on the presumption that a more rapid turnover (i.e. shorter term of office for governors) implied a lower degree of actual independence (Klomp \& de Haan, 2010). If the political

2 The turnover rate was calculated as $1 /$ the actual term of the governor. For instance, if the actual tenure of the governor is 4 years, the turnover rate is calculated as 0.25 . Since the government electoral cycle in any country is at least 4 years, the study claimed that a turnover rate that lies between 0.2 and 0.25 negatively affects CBI. 
authorities have the ability to appoint the governor, they will select those who will not challenge their policies. In the same way, frequent turnover may reflect the dismissal of governors that refuse to comply with the political authorities' instructions (Lybek, 1999b; Bezhoska, 2017). It is notable that the authors admitted that a low turnover rate does not necessarily imply a high level of independence as a relatively subservient governor may stay in office for a long time. The second indicator employed was the questionnaire based index of CBI (James, 2010; Ivanović, 2014). It was based on the responses to a survey administered to a sample of monetary policy specialists at some of the central banks included in the study during the 1980s (Parkin, 2012). The designed survey focused on the same issues covered by the legal index, in addition to other aspects like financial independence of the central bank and the adherence to the intermediate target (Kamaly \& Farrag, 2005). The results of the two measures indicated that central banks in developing countries were less independent than those in industrial countries. Despite their valuable contributions, the two studies were criticized for two reasons. First, the governor's turnover is considered a crude proxy for CBI and political interference, as low turnover could imply acquiescence to the government, while high turnover may be prompted by governor's opposition to political interference (Cargill, 2013). Moreover, governments might have other means to influence monetary policy other than dismissal of the governor (Hayo $\&$ Voigt, 2008). Also, turnover rate may be endogenous to economic and political circumstances, like inflation performance and political stability (Banaian, 2008). Second, the survey responses reported in the two studies were subjective and subject to small sample size and limited time periods (Ewiss, 2003; Cargill, 2013).

In an attempt to refine the turnover measure, Cukierman and Webb (1995) presented a modified concept; the political vulnerability of central bank governors. It accounted for the probability of removing the central bank governor from his office within six months of a change in government (Cukierman, 2006; Banaian, 2008). In other words, it measured the extent to which a change in the central bank governor is induced by changes in the executive authority. The higher the ratio, the higher the political influence on the central bank and, hence, the lower the degree of CBI. Using a sample of 67 developed and developing countries between 1950 and 1980, the study concluded that average vulnerability was higher in developing countries than in the developed ones. Such indicator is quite useful mainly for developing countries that suffer from weak law enforcement. Also, it provides a clearer picture of the relation between the government and the central bank (Kamaly \& Farrag, 2005).

In 2004, Cukierman presented an important study for assessing both legal and actual levels of independence for the Bank of Israel since its establishment in 
1954. He constructed a judgmental index for measuring actual independence and compared it to its legal counterpart (The legal index designed by CWN (1992)) to capture the divergence between legal and actual independence of the Bank of Israel overtime (Cukierman, 2006). The main contribution of the study was the use of the same codification system to measure both legal and actual independence. Thus, the judgmental index factored in various issues related to the freedom of central bank to conduct open market operations, size of budget deficit, the effectiveness of limitations on government borrowing from the central bank and the existence of inflation targets (Cukierman, 2007).

Hueng (2012) employed the Taylor reaction function as a measure of de facto CBI. Basically, central bank's policy reaction function described how monetary policy instruments, like interest rates respond to inflation and output gap. Thus, it reflected the behaviour of the central bank and its actual level of independence. In addition, the study analysed the relationship between various legal CBI measures and the newly constructed de facto measure for 18 OECD countries during the 1980s. It was concluded that legal limitations on the ability of the central bank to finance government deficit affected the central bank's behaviour towards inflation whilst other legal aspects like appointment, dismissal and tenure of the governor had no effect upon central bank's reaction to inflation.

The main criticism presented for this group of measures is the lack of a comprehensive measure for actual independence that can be applied to a large set of countries. Additionally, the measures presented are not comparable as each measure focused on a different aspect of CBI. Accordingly, de jure measures of CBI continue to dominate the research agenda (Banaian, 2008).

In conclusion, measurement literature has overemphasized the reliability of CBI measures and policy implications derived from them. In fact, these measures are not as informative as claimed and are subject to large classification problems (Cargill, 2013). This could be attributed to the lack of theory concerning the construction of the indices, the scale of measurement, and the averaging technique (Banaian, 2008). Legal measures of CBI are generally less subjective, more comprehensive and more applicable compared to actual measures. They allow for cross-country comparisons, however, do not reflect the true degree of independence, especially for developing countries (Berger \& de Haan, 1999; Hayo \& Hefeker, 2002). The majority of empirical studies focused on de jure measures compared to de facto measures. Also, there is a substantial gap in literature for studies covering both legal and actual CBI, as well as assessing the degree of deviation among them. To this end, the following section presents the proposed measures for CBI that attempt to overcome some of the drawbacks of the existing measures. 


\section{II) New Measures for CBI}

\section{A. New Measure for De Jure CBI}

The new de jure index incorporates elements related to independence, accountability and transparency of the central bank. It comprises most of the institutional arrangements proposed by the aforementioned studies. Compared to traditional indices, the present index expands existing measures by including several criteria that are scattered across various studies without being aggregated in a unified index, like conflict resolution mechanism, reappointment possibilities of the governing body of the central bank, indirect credit to government, lender of last resort mechanism, financial independence, accountability, transparency, and exchange rate policy. In addition, the index includes provisions related to both governor and central bank board, rather than alternating between them, which was typically the case in most of the previous studies. Lastly, the index excludes elements that are debatable with no consensus view regarding its impact on CBI, like banking supervision function ${ }^{3}$.

In coding each criterion, only information written in the legal documents governing the central bank is considered. This methodology makes it possible to estimate the degree of CBI with a minimal subjective judgment (Cukierman, 1992). The index is divided into ten main variables; each variable is divided into several criteria. The total number of criteria included in the index is 32 .

1. The central bank objective(s): The index favours setting price stability as the sole or main objective of the central bank. The institutional commitment to price stability provides a counter to time-inconsistency, resists the inflationary bias of governments, and ensures the credible commitment of monetary policy (Mishkin, 1998; Lybek, 1999a; Issing, 2006; Arnone et al., 2007; Romelli, 2015).

2. Policy formulation: This variable is related to the extent to which policy decisions are carried out by the central bank with the lowest degree of

3 The impact of banking supervision on CBI is debatable with no absolute judgment in literature regarding separating or combining the banking supervision task with monetary policy. Arguments for separating the two functions include potential loss in central bank's credibility with any financial crisis and possible contamination of monetary policy by supervisory considerations that could jeopardize both monetary policy and financial stability. On the other hand, entrusting the banking supervision function to central bank ensures coordination between monetary policy and prudential supervision. Additionally, it facilitates central bank's access to accurate and timely information regarding market conditions which assists in effective pursuit of monetary policy. 
government involvement. It comprises three main criteria; a) who formulates monetary policy, b) the existence of a conflict resolution mechanism that provides the central bank with the final authority in any disputes over its legally defined objectives, and c) whether the central bank charter allows the government to overrule the central bank or not. In this regard, central banks with wider authority to formulate monetary policy and to resist governments in cases of conflicts are categorized as most independent.

3. Governor: This variable assesses the autonomy of the central bank governor from any potential political pressure. It is analysed in relation to five main criteria: the terms of office of governor, its reappointment possibilities, the appointment and dismissal procedures and the incompatibility clause. In coding this variable, central banks in which the legal term of office of the governor is longer than the election cycle with no reappointment possibility, and in which appointment and potential dismissal procedures are carried out with little government involvement are classified as more independent. Concerning the list of incompatibility activities, central bank charters that do not incorporate an explicit incompatibility clause for the governor are penalized in recognition of the fact that this practice might produce conflict of interest which impairs CBI.

4. Central Bank Board: This variable comprises the same five criteria included in the governor variable. Besides, an additional criterion is added concerning the composition of the board members. A central bank board with no government or private sector representation is assigned the highest degree of independence. Such board eliminates all potential sources of conflict of interest that might lead to deviation from the central bank's main objective.

5. Limitations on Credit to Government: The proposed index favours prohibiting both central bank direct and indirect credit to government; otherwise various limitations should be imposed. Such restrictions safeguard the central bank against government pressure and allow the separation between monetary and fiscal policy, hence, strengthen CBI (Grilli et al., 1991; Wijnholds \& Hoogduin, 1994; Lybek, 1999a; Issing, 2006; Arnone et al., 2007). In principle, the stricter the limitations imposed on credit to government, the higher the degree of CBI.

6. Lender of Last Resort: The underlying index rewards ruled and limited lender of last resort facilities ${ }^{4}$ to the banking sector, since those provisions

\footnotetext{
Lender of last resort facilities should be directed only to illiquid institutions rather than insolvent ones. Also, facilities should be provided on a temporary basis with predetermined limits and against clearly defined collateral.
} 
tend to avert potential banking crises. Yet, it penalizes excessive discretionary liquidity mechanisms that endanger monetary policy and CBI.

7. Financial Independence: This variable assesses the right of the central bank to utilize its financial resources without external involvement (Ivanović, 2014). In coding this variable, the highest degree of independence is coded to central banks that own their capital, determine their budget internally and self-finance their losses without resorting to a third party, i.e. the government.

8. Accountability: The index incorporates the importance of applying the appropriate accountability procedures as means to support CBI. Having the proper accountability measures in place, ensures appropriate checks and balances and enhances the credibility of monetary policy (Wijnholds \& Hoogduin, 1994; Mishkin, 1998; Lybek, 1999a; De Sousa, 2001). Accountability procedures employed in the index include the periodic disclosure of central bank financial statements certified by an external independent auditor, as well as external monitoring of the central bank.

9. Transparency: This variable evaluates the degree of transparency that the law obliges the central bank to adopt. It identifies whether the relevant law necessitates the publishing of periodic reports on monetary policy and inflation reports. It is notable that transparency enhances the effectiveness and credibility of monetary policy (Dincer \& Eichengreen, 2014; Naini \& Naderian; 2016).

10. Foreign Exchange Policy: Central banks that are in charge of formulating and implementing exchange rate policy are coded the highest degree of independence on this variable. Such arrangement ensures consistency between monetary and exchange rate policy (Krušković, 2017).

Each of the 32 criteria is coded using a uniform scale ranging between 0 and 1 , with 0 implying the lowest degree of independence and 1 representing the highest degree of independence. The number of independence levels within each criterion varies based on the alternative legal characteristics related to this criterion. Specifically, if $x_{i}$ reflects the number of independence levels for the criteria $i$, the range [0.1] is divided into $x_{i}-1$ equal intervals. This would yield $x_{i}$ numerical coding that match the $\mathrm{x}_{\mathrm{i}}$ independence levels (Cukierman, 1992). For instance, if $\mathrm{x}_{\mathrm{i}}=7$, the numerical coding is $0,0.17,0.33,0.5,0.67,0.83$ and 1 . The underlying index follows a two-step aggregation process. In the first step, the 32 criteria are aggregated into ten main variables, each reflecting a certain element of CBI. Second, the ten variables are further aggregated to yield a single index measuring the degree of de jure CBI. The rationale behind this aggregation technique is to reduce the degree of multicollinearity among individual criteria and to accurately pinpoint the attribution of each variable to CBI (Cukierman, 1992). 
One final consideration is the choice of weights. Theoretically, weights assigned for each criterion reflect the relative importance and degree of influence that the underlying criterion has in terms of its contribution to CBI (Jácome, 2001; Pisha, 2011). However, with the absence of a monetary theory that guides the choice of weights, the proposed index applies the equal weighting technique to reduce the degree of subjectivity in the index (Sharpe \& Andrews, 2012; Gisselquist, 2014). Yet, since the new index is aggregated in two steps, applying equal weights for each criterion within each variable, implicitly implies an unequal weighting of the variables (i.e. variables grouping larger number of criteria are assigned higher weights). This would result in an unbalanced structure in the index (Organization for Economic Co-operation and Development - OECD, 2008; Romelli, 2015). To alleviate this problem, codes for each variable are calculated according to this formula:

Degree of independence for any variable $=\sum_{i=1}^{n}\left(\frac{1}{n} *\right.$ Scorefor Criteria $\left.i\right)$,

Where $n$ reflects the number of criteria included in the variable and i represents each criterion ${ }^{5}$.

Final Value of the De Jure Index $=\sum_{j=1}^{10}$ Scorefor Variable $_{j}$,

Where $j$ represents each of the ten variables included in the index.

The maximum score for the de jure index is 10, reflecting the highest degree of legal CBI.

Table 1: Proposed Index for Measuring De Jure CBI

\begin{tabular}{|c|c|c|c|}
\hline Variable & Criteria & Legal Characteristics & Score \\
\hline \multirow{5}{*}{$\begin{array}{l}\text { 1) } \\
\text { Objective(s) }\end{array}$} & \multirow{5}{*}{$\begin{array}{l}\text { Price stability } \\
\text { objective }\end{array}$} & $\begin{array}{l}\text { Price stability is mentioned as the only or major objective in the } \\
\text { charter }\end{array}$ & 1 \\
\hline & & $\begin{array}{l}\text { Price stability is mentioned as one goal with other compatible } \\
\text { objectives without priority given (i.e. financial stability) }\end{array}$ & 0.75 \\
\hline & & $\begin{array}{l}\text { Price stability is mentioned along with other conflicting } \\
\text { objectives (i.e. full employment) without priority given }\end{array}$ & 0.5 \\
\hline & & $\begin{array}{l}\text { Central bank charter does not include any provision concerning } \\
\text { objectives }\end{array}$ & 0.25 \\
\hline & & The stated objectives do not include price stability & 0 \\
\hline
\end{tabular}

5 For instance, in coding the governor variable, it encompasses 5 criteria. Thus the degree of CBI within this variable $=1 / 5^{*}$ Score of the "Terms of Office" criteria $+1 / 5{ }^{*}$ Score of the "Reappointment" criteria $+1 / 5^{\star}$ Score of the "Appointment" criteria $+1 / 5^{\star}$ Score of the "Dismissal" criteria $+1 / 5{ }^{*}$ Score of the "Incompatibility Clause" criteria. 


\begin{tabular}{|c|c|c|c|}
\hline \multirow{15}{*}{$\begin{array}{l}\text { 2) } \\
\text { Policy } \\
\text { formulation }\end{array}$} & \multirow{5}{*}{$\begin{array}{l}\text { Who formulates } \\
\text { monetary } \\
\text { policy? }\end{array}$} & Central bank alone & 1 \\
\hline & & Both central bank and government & 0.75 \\
\hline & & $\begin{array}{l}\text { Central bank participates with the government, but has little } \\
\text { influence }\end{array}$ & 0.5 \\
\hline & & Central bank only advises the government & 0.25 \\
\hline & & Government alone & 0 \\
\hline & \multirow{7}{*}{$\begin{array}{l}\text { Who has the } \\
\text { final authority } \\
\text { in conflict } \\
\text { resolution? }\end{array}$} & $\begin{array}{l}\text { Central bank has the final authority over issues clearly defined in } \\
\text { the law (like central bank objectives). }\end{array}$ & 1 \\
\hline & & $\begin{array}{l}\text { Central bank is independent concerning achieving its objective, } \\
\text { but the charter does not include any provision concerning } \\
\text { conflict resolution }\end{array}$ & 0.83 \\
\hline & & $\begin{array}{l}\text { In case of conflict, final decision is up to a council whose } \\
\text { members represent the central bank, executives and legislatures } \\
\text { (also could include the president) but in a transparent manner }\end{array}$ & 0.67 \\
\hline & & In case of conflict, the final decision is up to the legislature & 0.50 \\
\hline & & $\begin{array}{l}\text { Government has the final authority on policy issues not clearly } \\
\text { defined in the central bank charter }\end{array}$ & 0.33 \\
\hline & & $\begin{array}{l}\text { Government has the final authority on all policy issues but subject } \\
\text { to due process and possible protest by the central bank }\end{array}$ & 0.17 \\
\hline & & Government has unconditional authority over policy issues & 0 \\
\hline & \multirow{3}{*}{$\begin{array}{l}\text { The existence of } \\
\text { override clause } \\
\text { in the charter }\end{array}$} & Government is prohibited from overriding the central bank & 1 \\
\hline & & $\begin{array}{l}\text { Allowed under strict rules (in exceptional cases for limited time } \\
\text { after the parliamentary approval) }\end{array}$ & 0.50 \\
\hline & & $\begin{array}{l}\text { Unconditional override possible at the discretion of the } \\
\text { government }\end{array}$ & 0 \\
\hline \multirow{14}{*}{$\begin{array}{l}\text { 3) } \\
\text { Governor }\end{array}$} & \multirow{3}{*}{ Terms of office } & Exceeds the election cycle (i.e. over 5 years) & 1 \\
\hline & & Same as the election cycle & 0.5 \\
\hline & & Less than the election cycle or at the discretion of appointer & 0 \\
\hline & \multirow{4}{*}{$\begin{array}{l}\text { Reappointment } \\
\text { possibilities }\end{array}$} & Not allowed & 1 \\
\hline & & $\begin{array}{l}\text { Only one reappointment is possible in addition to the first } \\
\text { appointment }\end{array}$ & 0.67 \\
\hline & & $\begin{array}{l}\text { The central bank charter does not include any provision } \\
\text { concerning reappointment }\end{array}$ & 0.33 \\
\hline & & $\begin{array}{l}\text { Central bank charter permits governor's reappointment with no } \\
\text { limits }\end{array}$ & 0 \\
\hline & \multirow{7}{*}{$\begin{array}{l}\text { Who appoints } \\
\text { the governor? }\end{array}$} & $\begin{array}{l}\text { Double veto arrangement, whereby the central bank board } \\
\text { nominates and the president or the legislature appoints }\end{array}$ & 1 \\
\hline & & Appointment is carried out exclusively by the central bank board & 0.83 \\
\hline & & $\begin{array}{l}\text { Appointment is carried out by a council composed of members } \\
\text { from the central bank board, executives and legislatures }\end{array}$ & 0.67 \\
\hline & & Appointment is done exclusively by the legislature & 0.5 \\
\hline & & Appointment is done exclusively by the president & 0.33 \\
\hline & & $\begin{array}{l}\text { Appointment is done exclusively by the executive branch } \\
\text { collectively (i.e. the cabinet) }\end{array}$ & 0.17 \\
\hline & & $\begin{array}{l}\text { Appointment is done exclusively by some members of the } \\
\text { executive branch }\end{array}$ & 0 \\
\hline
\end{tabular}




\begin{tabular}{|c|c|c|c|}
\hline & \multirow{7}{*}{ Dismissal } & $\begin{array}{l}\text { Dismissal is allowed only for reasons not related to policy (i.e. } \\
\text { incapability or breach of law or misconduct) by rule of court or } \\
\text { independent tribunal. }\end{array}$ & 1 \\
\hline & & $\begin{array}{l}\text { Dismissal is allowed only for reasons not related to policy (i.e. } \\
\text { incapability or breach of law or misconduct) after the approval of } \\
\text { both the nominator and the appointer in a two-step process }\end{array}$ & 0.83 \\
\hline & & Dismissal is allowed at the discretion of the central bank board & 0.67 \\
\hline & & Dismissal is allowed at the discretion of the legislature & 0.5 \\
\hline & & Dismissal is allowed at the discretion of the president & 0.33 \\
\hline & & $\begin{array}{l}\text { Dismissal is allowed at the discretion of the government for policy } \\
\text { reasons }\end{array}$ & 0.17 \\
\hline & & $\begin{array}{l}\text { Unconditional dismissal is permitted at the government's } \\
\text { discretion or charter does not include dismissal clause }\end{array}$ & 0 \\
\hline & & $\begin{array}{l}\text { Governor is prohibited from holding any other office in } \\
\text { government, while in office }\end{array}$ & 1 \\
\hline & $\begin{array}{l}\text { Incompatibility } \\
\text { clause }\end{array}$ & $\begin{array}{l}\text { Governor is generally not allowed to hold any other office in } \\
\text { government unless authorized by the executive branch }\end{array}$ & 0.5 \\
\hline & & $\begin{array}{l}\text { Central bank charter does not prohibit governor from holding } \\
\text { other office in government, while in office }\end{array}$ & 0 \\
\hline \multirow{19}{*}{$\begin{array}{l}\text { 4) } \\
\text { Central Bank } \\
\text { Board }\end{array}$} & \multirow{3}{*}{ Terms of office } & Exceeds the election cycle (i.e. over 5 years) & 1 \\
\hline & & Same as the election cycle & 0.5 \\
\hline & & less than the election cycle or at the discretion of appointer & 0 \\
\hline & \multirow{4}{*}{$\begin{array}{l}\text { Reappointment } \\
\text { possibilities }\end{array}$} & Not allowed & 1 \\
\hline & & $\begin{array}{l}\text { Only one reappointment is possible in addition to the first } \\
\text { appointment }\end{array}$ & 0.67 \\
\hline & & $\begin{array}{l}\text { The central bank charter does not include any provision } \\
\text { concerning reappointment }\end{array}$ & 0.33 \\
\hline & & Central bank charter permits reappointment with no limits & 0 \\
\hline & \multirow{5}{*}{$\begin{array}{l}\text { Who appoints } \\
\text { the central bank } \\
\text { board? }\end{array}$} & $\begin{array}{l}\text { Double veto arrangement, whereby, central bank governor } \\
\text { nominates and the president or the legislature appoints }\end{array}$ & 1 \\
\hline & & Appointment is carried out exclusively by the legislature & 0.75 \\
\hline & & Appointment is done exclusively by the president & 0.5 \\
\hline & & $\begin{array}{l}\text { Appointment is done exclusively by the executive branch } \\
\text { collectively (i.e. the cabinet) }\end{array}$ & 0.25 \\
\hline & & $\begin{array}{l}\text { Appointment is done exclusively by some members of the } \\
\text { executive branch }\end{array}$ & 0 \\
\hline & \multirow{7}{*}{$\begin{array}{l}\text { Dismissal of any } \\
\text { board member }\end{array}$} & $\begin{array}{l}\text { Dismissal is allowed only for reasons not related to policy (i.e. } \\
\text { incapability or breach of law or misconduct) by rule of court or } \\
\text { independent tribunal }\end{array}$ & 1 \\
\hline & & $\begin{array}{l}\text { Dismissal is allowed only for reasons not related to policy (i.e. } \\
\text { incapability or breach of law or misconduct) after the approval of } \\
\text { both the nominator and the appointer in a two-step process }\end{array}$ & 0.83 \\
\hline & & Dismissal is allowed at the discretion of the central bank board & 0.67 \\
\hline & & Dismissal is allowed at the discretion of the legislature & 0.50 \\
\hline & & Dismissal is allowed at the discretion of the president & 0.33 \\
\hline & & $\begin{array}{l}\text { Dismissal is allowed at the discretion of the government for policy } \\
\text { reasons }\end{array}$ & 0.17 \\
\hline & & $\begin{array}{l}\text { Unconditional dismissal is permitted at the government's } \\
\text { discretion or charter does not include dismissal clause }\end{array}$ & 0 \\
\hline
\end{tabular}




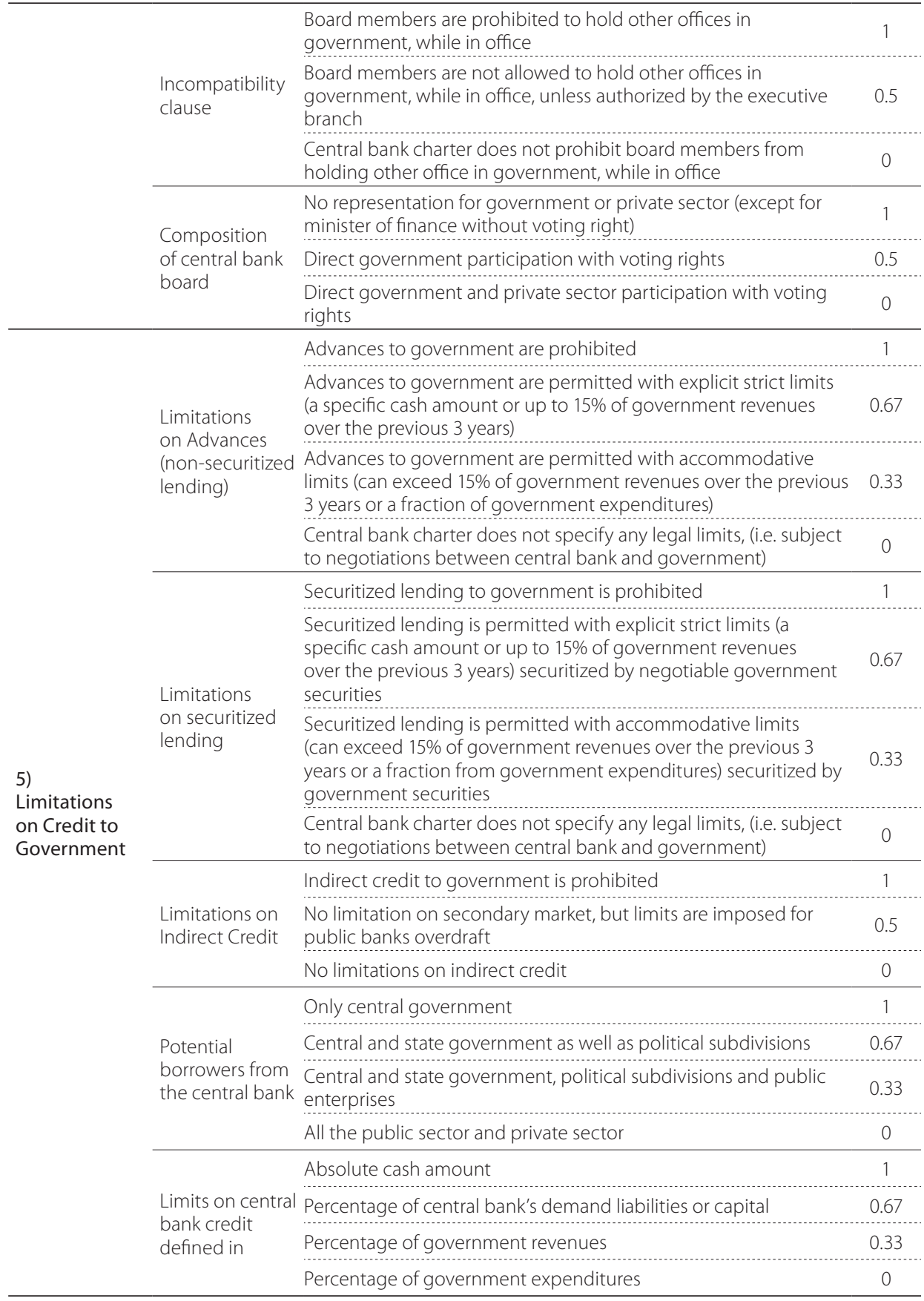




\begin{tabular}{|c|c|c|c|}
\hline & \multirow{4}{*}{$\begin{array}{l}\text { Maturity of } \\
\text { loans }\end{array}$} & Within 6 months & 1 \\
\hline & & Within 1 year & 0.67 \\
\hline & & More than 1 year & 0.33 \\
\hline & & No legal upper bounds on maturity of loans & 0 \\
\hline & \multirow{5}{*}{$\begin{array}{l}\text { Interest rates on } \\
\text { loans }\end{array}$} & Interest rates are market rates & 1 \\
\hline & & Interest rates cannot be lower than a certain floor & 0.75 \\
\hline & & Interest rates cannot exceed a certain ceiling & 0.5 \\
\hline & & $\begin{array}{l}\text { Central bank charter does not include any explicit legal provisions } \\
\text { concerning interest rates (i.e. it is determined by the central bank) }\end{array}$ & 0.25 \\
\hline & & $\begin{array}{l}\text { Central bank charter stipulates no interest charge on government } \\
\text { borrowing }\end{array}$ & 0 \\
\hline & \multirow{3}{*}{$\begin{array}{l}\text { Central bank's } \\
\text { participation } \\
\text { in the primary } \\
\text { market for } \\
\text { government } \\
\text { securities }\end{array}$} & $\begin{array}{l}\text { Central bank is legally prohibited from participating in the primary } \\
\text { market for government securities }\end{array}$ & 1 \\
\hline & & $\begin{array}{l}\text { Central bank is not prohibited, yet, its activity in the primary } \\
\text { market is discretionary }\end{array}$ & 0.5 \\
\hline & & $\begin{array}{l}\text { Central bank charter does not include any clause concerning } \\
\text { the participation of central bank in the primary market for } \\
\text { government securities }\end{array}$ & 0 \\
\hline \multirow{3}{*}{$\begin{array}{l}\text { 6) } \\
\text { Lender of } \\
\text { Last Resort } \\
\text { Function }\end{array}$} & \multirow{3}{*}{$\begin{array}{l}\text { Lender of last } \\
\text { resort function }\end{array}$} & $\begin{array}{l}\text { Central bank provides legally regulated emergency loans, with } \\
\text { limits to the amounts }\end{array}$ & 1 \\
\hline & & $\begin{array}{l}\text { Central bank provides legally regulated emergency loans, without } \\
\text { limits to the amount }\end{array}$ & 0.5 \\
\hline & & Central bank applies discretionary policy for emergency loans & 0 \\
\hline \multirow{12}{*}{$\begin{array}{l}\text { 7) } \\
\text { Financial } \\
\text { Independence }\end{array}$} & \multirow{5}{*}{$\begin{array}{l}\text { Ownership of } \\
\text { central bank } \\
\text { equity capital }\end{array}$} & Central bank's capital is owned by the central bank & 1 \\
\hline & & Government owns less than half of the central bank capital & 0.75 \\
\hline & & Government owns more than half of the central bank capital & 0.5 \\
\hline & & Government owns all the central bank capital & 0.25 \\
\hline & & Private sector owns the central bank capital & 0 \\
\hline & \multirow{4}{*}{$\begin{array}{l}\text { Who } \\
\text { determines the } \\
\text { central bank's } \\
\text { internal budget }\end{array}$} & $\begin{array}{l}\text { Central bank board alone determines the internal budget or with } \\
\text { the approval of the legislature or the president }\end{array}$ & 1 \\
\hline & & $\begin{array}{l}\text { Only the legislature or the president determines the internal } \\
\text { budget of the central bank }\end{array}$ & 0.67 \\
\hline & & $\begin{array}{l}\text { Only the executive branch determines the internal budget of the } \\
\text { central bank }\end{array}$ & 0.33 \\
\hline & & $\begin{array}{l}\text { The law doesn't specify who determines the internal budget of } \\
\text { the central bank }\end{array}$ & 0 \\
\hline & \multirow{3}{*}{$\begin{array}{l}\text { Potential central } \\
\text { bank's loss } \\
\text { coverage }\end{array}$} & $\begin{array}{l}\text { Losses are covered by general reserves, special reserves, or by } \\
\text { revaluation account and other internal funds }\end{array}$ & 1 \\
\hline & & $\begin{array}{l}\text { Losses are covered only by general reserves, and the rest from the } \\
\text { state budget }\end{array}$ & 0.5 \\
\hline & & Losses are covered only by the state budget & 0 \\
\hline \multirow{3}{*}{$\begin{array}{l}\text { 8) } \\
\text { Accountability }\end{array}$} & \multirow{3}{*}{$\begin{array}{l}\text { External } \\
\text { Monitoring }\end{array}$} & Central bank shall appear before the legislature & 1 \\
\hline & & Central bank shall appear before the president & 0.5 \\
\hline & & Central bank shall appear before the government & 0 \\
\hline
\end{tabular}




\begin{tabular}{|c|c|c|c|}
\hline & \multirow{3}{*}{$\begin{array}{l}\text { Audit of } \\
\text { financial } \\
\text { statements }\end{array}$} & $\begin{array}{l}\text { Independent external auditor or audit committee in addition to } \\
\text { the auditor-general of the government audits the annual financial } \\
\text { statement that is in conformity with international standards }\end{array}$ & 1 \\
\hline & & $\begin{array}{l}\text { Only the auditor-general of the government audits the annual } \\
\text { financial statement }\end{array}$ & 0.5 \\
\hline & & $\begin{array}{l}\text { Annual financial statements are submitted to the supervisor of } \\
\text { the central bank without a formal requirement for auditing (only } \\
\text { internal audit) }\end{array}$ & 0 \\
\hline & \multirow{3}{*}{$\begin{array}{l}\text { Disclosure of } \\
\text { the central } \\
\text { bank's financial } \\
\text { statements }\end{array}$} & $\begin{array}{l}\text { Central bank is legally obliged to publish its periodic financial } \\
\text { statements along with more frequent summary of balance sheet } \\
\text { information }\end{array}$ & 1 \\
\hline & & $\begin{array}{l}\text { Central bank is legally obliged to publish its financial statements } \\
\text { only once a year }\end{array}$ & 0.5 \\
\hline & & $\begin{array}{l}\text { There is no explicit provision in the central bank charter that } \\
\text { requires the disclosure of financial statements }\end{array}$ & 0 \\
\hline \multirow{3}{*}{$\begin{array}{l}\text { 9) } \\
\text { Transparency }\end{array}$} & \multirow{3}{*}{$\begin{array}{l}\text { Publishing of } \\
\text { reports on } \\
\text { monetary policy } \\
\text { and inflation } \\
\text { reports }\end{array}$} & $\begin{array}{l}\text { Central bank is legally required to publish periodic reports } \\
\text { (annual, semi-annual, monthly) about monetary operations, } \\
\text { inflation reports and any information needed }\end{array}$ & 1 \\
\hline & & Central bank is legally required to publish only annual reports & 0.5 \\
\hline & & Central bank is not legally obligated to publish any information & 0 \\
\hline \multirow{3}{*}{$\begin{array}{l}\text { 10) } \\
\text { Foreign } \\
\text { Exchange } \\
\text { Policy }\end{array}$} & \multirow{3}{*}{$\begin{array}{l}\text { Who formulates } \\
\text { and implements } \\
\text { exchange rate } \\
\text { policy }\end{array}$} & Only central bank & 1 \\
\hline & & Central bank along with government & 0.5 \\
\hline & & Government alone & 0 \\
\hline
\end{tabular}

\section{B. New Measure for De Facto CBI}

The proposed index analyses the behaviour of the central bank besides the practical arrangements related to its independence in an attempt to reach a more accurate indication of the actual degree of CBI. In constructing the de facto index, three objectives are considered; first, the need to compose a de facto index that well matches the de jure index in order to facilitate contrasting with the de jure index. Second, to focus on independence attributes that could be codified objectively with a minimum degree of subjectivity. This objective is rather problematic, as the de facto index relies on the actual institutional practice of central banks rather than concrete legal provisions. Third, to include criteria that can provide some account for the evolution of actual CBI over time. Trading off these three objectives, the present study constructs a de facto CBI index that is composed of ten main variables, similar to those included in the de jure one. Each of the ten variables is further divided into several criteria. The index incorporates a total of 37 criteria that are expected to reveal the actual degree of CBI. It is notable that the index applies almost the same codification system as the de jure one. The main difference between the two indices is the methodology applied to measure the degree of CBI. 
Compared to previous indicators for measuring de facto CBI, the present index is relatively more comprehensive as it incorporates almost all the previous indicators for measuring de facto CBI like, monetary policy reaction function, the turnover ratio and the political vulnerability indicator, in addition to coding new dimensions that are not included in previous measures for de facto CBI, like independence of central bank board, indirect credit to government, lender of last resort function, financial independence, accountability, and transparency. Over and above, the present study attempts to codify de facto CBI criteria in a more objective and precise manner rather than the judgmental view applied in some of the previous studies, like, Cukierman (2004) and Cukierman (2007). Finally, the de facto index mimics the de jure one to a large extent which facilitates comparison.

The variables of the present index are:

1. Central bank objective(s): To determine the actual objective of central bank, two criteria are examined. a) Whether price stability is the main objective of the central bank, and b) Whether there is an explicit target for inflation or prices that is publicly announced by the central bank. The first criterion is examined by analysing the behaviour of the central bank, as described by its reaction function. Thus, the Taylor-type reaction function could be employed to assess the central bank's behaviour. This function specifies the interest rate response to inflation and output gap, using the following equation: $i_{t}=r^{*}+\pi_{t}+\lambda\left(\pi_{t}-\pi^{T}\right)+\alpha_{y} y_{t}$, where; $i_{t}$ is the nominal interest rate, $r^{*}$ is the equilibrium real interest rate, $\pi_{t}$ is the annual inflation rate, $\pi^{T}$ is the target level of $\pi_{t}$ and $y_{t}$ is the percentage deviation of real output from its potential level (SánchezFung, 2000; Gerlach-Kristen, 2003; Hueng, 2012).

2. Policy formulation: This variable covers two criteria related to the monetary policy formulation and the conflict resolution mechanism. To code the first criteria, the study analyses the actual practice related to who formulates monetary policy and this is examined through identifying the party entitled in practice to take monetary policy decisions and release them to the public, while the conflict resolution criteria are examined by assessing the authority of the central bank against the government in previous disputes over monetary policy.

3. Governor: This variable encompasses six criteria related to term of office, reappointment possibilities, appointment procedures, dismissal procedures and politically inspired dismissal and incompatibility clause. To code these criteria, the study relies on the turnover rate and the political vulnerability indicator. In addition to, analysing the practical procedures 
related to governor's appointment, previous dismissal incidences, whether any of the previous governors held office in government, while in office and whether there exists any case for governor's reappointment or not.

4. Central bank board: This variable incorporates seven criteria. The first six criteria are the same as those included in the governor variable and hence are assessed using the same methodology. While the seventh criteria is related to the composition of board.

5. Limitations on credit to government: This variable encompasses seven criteria related to limitations on central bank's credit to government. Data on central bank credit to government is analysed to indicate whether legal limits in terms of amount, maturity, interest rate and eligible borrowers as well as restrictions on the participation of the central bank in the primary market for government securities are breached in practice or not.

6. Lender of last resort function: Data on central bank emergency loans to the banking sector is analysed to find out whether those loans are provided under strict limits or on a discretionary basis.

7. Financial independence: This variable covers three criteria; whether the government owns central bank's capital or not, whether it is the central bank board that determines the internal budget in practice or not and how are central bank losses actually covered.

8. Accountability: Three accountability criteria are included in this variable, namely, whether the central bank is subject to external monitoring by a third party in practice and who is this party, whether the central bank's financial statements are audited by external auditors, and whether the central bank discloses its financial statements to the public in a timely manner or not.

9. Transparency: The transparency variable focuses on five criteria of transparency related to the release of information on monetary variables and inflation, as well as publishing central bank's forecasts and forward looking analysis. Besides, it incorporates the disclosure of policy decisions and minutes of the monetary policy committee (MPC) meetings with explanation to the public in a timely manner. It is notable that this variable implicitly reflects the quality of the reports produced by the research department at the central bank, and hence the quality of the research department itself. Cukierman (1992) claimed that this factor is an important element of de facto CBI. A central bank's governor who is backed by a relatively strong research department is perceived as an impartial provider of reliable information about the economy, and hence is expected to have more power vis-a-vis the government.

10. Exchange Rate Policy: This variable identifies whether exchange rate policy is formulated and implemented by the central bank or not, through 
analysing practical arrangements related to exchange rate policy in terms of who take exchange rate decisions and announce it to the public.

The methodology applied for coding each criterion, the two steps aggregating process and equal weighting technique for each of the ten variables are the same as that of the de jure index. Specifically, each of the 37 criteria is coded using a uniform scale from 0 to 1 . Yet, the number of independence levels in most of the criteria included is lower than that of the de jure index. Since the data collected is based on interpretations and assessment of practical arrangements, simple coding technique is employed to simplify the data collection process and reduce the degree of subjectivity inherent in more sophisticated coding. In view of that, the maximum independence score is 10 (as in the de jure index).

Table 2: Proposed Index for Measuring De Facto CBI

\begin{tabular}{|c|c|c|c|c|}
\hline Variable & Criteria & Characteristics & Score & Methodology \\
\hline \multirow{4}{*}{ 1) Objective(s) } & \multirow{2}{*}{$\begin{array}{l}\text { Price stability } \\
\text { objective }\end{array}$} & Price stability is the main policy objective & 1 & \multirow{2}{*}{$\begin{array}{l}\text { Applying Taylor- type } \\
\text { reaction function }\end{array}$} \\
\hline & & $\begin{array}{l}\text { Price stability is not the main policy } \\
\text { objective }\end{array}$ & 0 & \\
\hline & \multirow{2}{*}{$\begin{array}{l}\text { Existence of an } \\
\text { explicit target } \\
\text { for inflation or } \\
\text { prices }\end{array}$} & $\begin{array}{l}\text { There exists an explicit target that is } \\
\text { announced to the public, and the central } \\
\text { bank abides by }\end{array}$ & 1 & \multirow{2}{*}{$\begin{array}{l}\text { Analysing the } \\
\text { information released } \\
\text { by the central bank } \\
\text { concerning inflation or } \\
\text { price target }\end{array}$} \\
\hline & & $\begin{array}{l}\text { There is no explicit target for inflation } \\
\text { or prices (or there exists a target but } \\
\text { the central bank does not abide by in } \\
\text { practice) }\end{array}$ & 0 & \\
\hline \multirow{6}{*}{$\begin{array}{l}\text { 2) Policy } \\
\text { formulation }\end{array}$} & \multirow{3}{*}{$\begin{array}{l}\text { Who formulates } \\
\text { monetary } \\
\text { policy? }\end{array}$} & Central bank alone & 1 & \multirow{3}{*}{$\begin{array}{l}\text { Analysing the } \\
\text { behaviour of the } \\
\text { central bank and its } \\
\text { monetary decisions }\end{array}$} \\
\hline & & Both central bank and government & 0.5 & \\
\hline & & Government alone & 0 & \\
\hline & \multirow{3}{*}{$\begin{array}{l}\text { Who has the } \\
\text { final authority } \\
\text { in conflicts } \\
\text { over monetary } \\
\text { policy? }\end{array}$} & The central bank has the final decision & 1 & \multirow{3}{*}{$\begin{array}{l}\text { Analysing the practical } \\
\text { arrangements } \\
\text { followed in case } \\
\text { of conflicts over } \\
\text { monetary policy }\end{array}$} \\
\hline & & $\begin{array}{l}\text { Government can have final authority } \\
\text { under strict rules and in a transparent } \\
\text { manner (i.e.in exceptional cases only } \\
\text { for limited time after the parliamentary } \\
\text { approval) }\end{array}$ & 0.5 & \\
\hline & & $\begin{array}{l}\text { Government has final authority with loose } \\
\text { or no limits }\end{array}$ & 0 & \\
\hline \multirow{6}{*}{ 3) Governor } & \multirow{3}{*}{ Terms of office } & $\begin{array}{l}\text { Exceeds the election cycle (i.e. over } 5 \\
\text { years) }\end{array}$ & 1 & \multirow{3}{*}{$\begin{array}{l}\text { Calculating the } \\
\text { turnover rate of the } \\
\text { governor }\end{array}$} \\
\hline & & Same as the election cycle & 0.5 & \\
\hline & & Less than the election cycle & 0 & \\
\hline & \multirow{3}{*}{$\begin{array}{l}\text { Reappointment } \\
\text { possibilities }\end{array}$} & Not allowed & 1 & \multirow{3}{*}{$\begin{array}{l}\text { Is there any case } \\
\text { of governor's } \\
\text { reappointment? }\end{array}$} \\
\hline & & $\begin{array}{l}\text { Only one reappointment is possible in } \\
\text { addition to the first appointment }\end{array}$ & 0.5 & \\
\hline & & More than one reappointment is possible & 0 & \\
\hline
\end{tabular}




\begin{tabular}{|c|c|c|c|c|}
\hline & \multirow{7}{*}{$\begin{array}{l}\text { Who appoints } \\
\text { the governor? }\end{array}$} & $\begin{array}{l}\text { Double veto arrangement whereby the } \\
\text { central bank board nominates and the } \\
\text { president or the legislature appoints }\end{array}$ & 1 & \multirow{7}{*}{$\begin{array}{l}\text { Analysing practical } \\
\text { procedures related to } \\
\text { appointment }\end{array}$} \\
\hline & & $\begin{array}{l}\text { Appointment is carried out exclusively by } \\
\text { the central bank board }\end{array}$ & 0.83 & \\
\hline & & $\begin{array}{l}\text { Appointment is carried out by a council } \\
\text { composed of members from the central } \\
\text { bank board, executives and legislatures }\end{array}$ & 0.67 & \\
\hline & & $\begin{array}{l}\text { Appointment is done exclusively by the } \\
\text { legislature }\end{array}$ & 0.5 & \\
\hline & & $\begin{array}{l}\text { Appointment is done exclusively by the } \\
\text { president }\end{array}$ & 0.33 & \\
\hline & & $\begin{array}{l}\text { Appointment is done exclusively by the } \\
\text { executive branch collectively (i.e. the } \\
\text { cabinet) }\end{array}$ & 0.17 & \\
\hline & & $\begin{array}{l}\text { Appointment is done exclusively by some } \\
\text { members of the executive branch }\end{array}$ & 0 & \\
\hline & \multirow{6}{*}{$\begin{array}{l}\text { Who can } \\
\text { dismiss the } \\
\text { governor? }\end{array}$} & $\begin{array}{l}\text { Dismissal is allowed only by rule of court } \\
\text { or independent tribunal }\end{array}$ & 1 & \multirow{6}{*}{$\begin{array}{l}\text { Analysing practical } \\
\text { procedures related to } \\
\text { dismissal }\end{array}$} \\
\hline & & $\begin{array}{l}\text { Dismissal is allowed with the approval of } \\
\text { both the nominator and the appointer in } \\
\text { a two-step process }\end{array}$ & 0.8 & \\
\hline & & $\begin{array}{l}\text { Dismissal is allowed after the approval of } \\
\text { the central bank board }\end{array}$ & 0.6 & \\
\hline & & $\begin{array}{l}\text { Dismissal is allowed after the approval of } \\
\text { the legislature }\end{array}$ & 0.4 & \\
\hline & & $\begin{array}{l}\text { Dismissal is allowed after the approval of } \\
\text { the president }\end{array}$ & 0.2 & \\
\hline & & $\begin{array}{l}\text { Dismissal is allowed after the approval of } \\
\text { the executives }\end{array}$ & 0 & \\
\hline & \multirow{2}{*}{$\begin{array}{l}\text { Politically } \\
\text { inspired } \\
\text { dismissal }\end{array}$} & Politically inspired dismissal is not allowed & 1 & \multirow{2}{*}{$\begin{array}{l}\text { Calculating the } \\
\text { political vulnerability } \\
\text { indicator }\end{array}$} \\
\hline & & Politically inspired dismissal is allowed & 0 & \\
\hline & \multirow{2}{*}{$\begin{array}{l}\text { Incompatibility } \\
\text { clause }\end{array}$} & $\begin{array}{l}\text { The governor does not hold any other } \\
\text { office in government, while in office }\end{array}$ & 1 & \multirow{2}{*}{$\begin{array}{l}\text { Does the governor } \\
\text { hold office in } \\
\text { government, while in } \\
\text { office? }\end{array}$} \\
\hline & & $\begin{array}{l}\text { The governor holds another office in } \\
\text { government, while in office }\end{array}$ & 0 & \\
\hline \multirow{6}{*}{$\begin{array}{l}\text { 4) Central } \\
\text { Bank Board }\end{array}$} & \multirow{3}{*}{ Terms of office } & $\begin{array}{l}\text { Exceeds the election cycle (i.e. over } 5 \\
\text { years) }\end{array}$ & 1 & \multirow{3}{*}{$\begin{array}{l}\text { Calculating the } \\
\text { turnover rate of the } \\
\text { board }\end{array}$} \\
\hline & & Same as the election cycle & 0.5 & \\
\hline & & less than the election cycle & 0 & \\
\hline & \multirow{3}{*}{$\begin{array}{l}\text { Reappointment } \\
\text { possibilities of } \\
\text { board }\end{array}$} & Not allowed & 1 & \multirow{3}{*}{$\begin{array}{l}\text { Is there any } \\
\text { case of board's } \\
\text { reappointment? }\end{array}$} \\
\hline & & $\begin{array}{l}\text { Only one reappointment is possible in } \\
\text { addition to the first appointment }\end{array}$ & 0.5 & \\
\hline & & $\begin{array}{l}\text { More than one reappointment is } \\
\text { possible }\end{array}$ & 0 & \\
\hline
\end{tabular}




\begin{tabular}{|c|c|c|c|c|}
\hline & \multirow{5}{*}{$\begin{array}{l}\text { Who appoints } \\
\text { the central bank } \\
\text { board? }\end{array}$} & $\begin{array}{l}\text { Double veto arrangement whereby the } \\
\text { central bank governor nominates and } \\
\text { the president or the legislature appoints }\end{array}$ & 1 & \multirow{5}{*}{$\begin{array}{l}\text { Analysing practical } \\
\text { procedures related to } \\
\text { appointment }\end{array}$} \\
\hline & & $\begin{array}{l}\text { Appointment is carried out exclusively by } \\
\text { the legislature }\end{array}$ & 0.75 & \\
\hline & & $\begin{array}{l}\text { Appointment is done exclusively by the } \\
\text { president }\end{array}$ & 0.5 & \\
\hline & & $\begin{array}{l}\text { Appointment is done exclusively by the } \\
\text { executive branch collectively (i.e. the } \\
\text { cabinet) }\end{array}$ & 0.25 & \\
\hline & & $\begin{array}{l}\text { Appointment is done exclusively by } \\
\text { some members of the executive branch }\end{array}$ & 0 & \\
\hline & \multirow{6}{*}{$\begin{array}{l}\text { Who can } \\
\text { dismiss any } \\
\text { board member? }\end{array}$} & $\begin{array}{l}\text { Dismissal is allowed only by rule of court } \\
\text { or independent tribunal }\end{array}$ & 1 & \multirow{6}{*}{$\begin{array}{l}\text { Analysing practical } \\
\text { procedures related to } \\
\text { dismissal }\end{array}$} \\
\hline & & $\begin{array}{l}\text { Dismissal is allowed under the approval } \\
\text { of both the nominator and the } \\
\text { appointer in a two-step process }\end{array}$ & 0.8 & \\
\hline & & $\begin{array}{l}\text { Dismissal is allowed after the approval of } \\
\text { the central bank board }\end{array}$ & 0.6 & \\
\hline & & $\begin{array}{l}\text { Dismissal is allowed after the approval of } \\
\text { the legislature }\end{array}$ & 0.4 & \\
\hline & & $\begin{array}{l}\text { Dismissal is allowed after the approval } \\
\text { of the president }\end{array}$ & 0.2 & \\
\hline & & $\begin{array}{l}\text { Dismissal is allowed after the approval of } \\
\text { the executives }\end{array}$ & 0 & \\
\hline & \multirow{2}{*}{$\begin{array}{l}\text { Politically } \\
\text { inspired } \\
\text { dismissal }\end{array}$} & Politically Inspired dismissal is not allowed & 1 & \multirow{2}{*}{$\begin{array}{l}\text { Calculating the } \\
\text { political vulnerability } \\
\text { indicator }\end{array}$} \\
\hline & & Politically Inspired dismissal is allowed & 0 & \\
\hline & \multirow{2}{*}{$\begin{array}{l}\text { Incompatibility } \\
\text { clause }\end{array}$} & $\begin{array}{l}\text { No board member holds office in } \\
\text { government }\end{array}$ & 1 & \multirow{2}{*}{$\begin{array}{l}\text { Does any board } \\
\text { member hold office in } \\
\text { government? }\end{array}$} \\
\hline & & $\begin{array}{l}\text { Some board members hold another } \\
\text { office in government }\end{array}$ & 0 & \\
\hline & \multirow{3}{*}{$\begin{array}{l}\text { Composition } \\
\text { of central bank } \\
\text { board }\end{array}$} & $\begin{array}{l}\text { No representation for government or } \\
\text { private sector (except for minister of } \\
\text { finance without voting right) }\end{array}$ & 1 & \multirow{3}{*}{$\begin{array}{l}\text { Analysing the } \\
\text { composition of board } \\
\text { and voting rights }\end{array}$} \\
\hline & & $\begin{array}{l}\text { Direct government participation with } \\
\text { voting rights }\end{array}$ & 0.5 & \\
\hline & & $\begin{array}{l}\text { Direct government and private sector } \\
\text { participation with voting rights }\end{array}$ & 0 & \\
\hline \multirow{3}{*}{$\begin{array}{l}\text { 5) Limitations } \\
\text { on Credit to } \\
\text { Government }\end{array}$} & \multirow{3}{*}{$\begin{array}{l}\text { Advances } \\
\text { (limitations on } \\
\text { non-securitized } \\
\text { lending) }\end{array}$} & $\begin{array}{l}\text { No advances are provided to } \\
\text { government }\end{array}$ & 1 & \multirow{3}{*}{$\begin{array}{l}\text { Analysing data on } \\
\text { advances provided to } \\
\text { government }\end{array}$} \\
\hline & & $\begin{array}{l}\text { Advances are provided within the } \\
\text { legally approved limits }\end{array}$ & 0.5 & \\
\hline & & $\begin{array}{l}\text { Advances are provided but exceeds the } \\
\text { legal limits }\end{array}$ & 0 & \\
\hline
\end{tabular}




\begin{tabular}{|c|c|c|c|c|}
\hline & \multirow{3}{*}{$\begin{array}{l}\text { Limitations } \\
\text { on securitized } \\
\text { lending }\end{array}$} & $\begin{array}{l}\text { Central bank does not provide } \\
\text { government with securitized Lending }\end{array}$ & 1 & \multirow{3}{*}{$\begin{array}{l}\text { Analysing data } \\
\text { on securitized } \\
\text { lending provided to } \\
\text { government }\end{array}$} \\
\hline & & $\begin{array}{l}\text { Central bank provides government with } \\
\text { securitized lending within the legally } \\
\text { approved limits }\end{array}$ & 0.5 & \\
\hline & & $\begin{array}{l}\text { Central bank provides government with } \\
\text { securitized lending but violates the } \\
\text { legally approved limits }\end{array}$ & 0 & \\
\hline & \multirow{3}{*}{$\begin{array}{l}\text { Limitations on } \\
\text { indirect credit }\end{array}$} & $\begin{array}{l}\text { Central bank does not provide indirect } \\
\text { credit to government. }\end{array}$ & 1 & \multirow{3}{*}{$\begin{array}{l}\text { Analysing data } \\
\text { on indirect credit } \\
\text { provided to } \\
\text { government }\end{array}$} \\
\hline & & $\begin{array}{l}\text { Central bank provide indirect credit within } \\
\text { the legally specified limitations }\end{array}$ & 0.5 & \\
\hline & & $\begin{array}{l}\text { Central bank provide indirect credit, but } \\
\text { violates the legally specified limitations }\end{array}$ & 0 & \\
\hline & \multirow{4}{*}{$\begin{array}{l}\text { Potential } \\
\text { borrowers from } \\
\text { central bank }\end{array}$} & Only central government & 1 & \multirow{4}{*}{$\begin{array}{l}\text { Analysing data on } \\
\text { central bank credit to } \\
\text { various parties }\end{array}$} \\
\hline & & $\begin{array}{l}\text { Central and state government as well as } \\
\text { political subdivisions }\end{array}$ & 0.67 & \\
\hline & & $\begin{array}{l}\text { Central and state government, political } \\
\text { subdivisions and public enterprises }\end{array}$ & 0.33 & \\
\hline & & All the public sector and private sector & 0 & \\
\hline & \multirow{3}{*}{$\begin{array}{l}\text { Maturity of } \\
\text { loans }\end{array}$} & Within 6 months & 1 & \multirow{3}{*}{$\begin{array}{l}\text { Calculating the } \\
\text { maturity of Central } \\
\text { bank loans to } \\
\text { government }\end{array}$} \\
\hline & & Within 1 year & 0.5 & \\
\hline & & More than 1 year & 0 & \\
\hline & \multirow{4}{*}{$\begin{array}{l}\text { Interest rates on } \\
\text { loans }\end{array}$} & Market rates & 1 & \multirow{4}{*}{$\begin{array}{l}\text { Analysing interest rate } \\
\text { on central bank loans } \\
\text { to government }\end{array}$} \\
\hline & & $\begin{array}{l}\text { As legally specified (if legal limits are } \\
\text { different than market rates) }\end{array}$ & 0.67 & \\
\hline & & Violates the legal limits & 0.33 & \\
\hline & & Loans are non-interest bearing & 0 & \\
\hline & \multirow{3}{*}{$\begin{array}{l}\text { Central bank's } \\
\text { participation } \\
\text { in the primary } \\
\text { market for } \\
\text { government } \\
\text { securities }\end{array}$} & $\begin{array}{l}\text { Central bank does not participate in the } \\
\text { primary market for government securities }\end{array}$ & 1 & \multirow{3}{*}{$\begin{array}{l}\text { Analysing data on } \\
\text { market participants in } \\
\text { the primary market for } \\
\text { government securities }\end{array}$} \\
\hline & & $\begin{array}{l}\text { Central bank occasionally participates } \\
\text { in the primary market for government } \\
\text { securities }\end{array}$ & 0.5 & \\
\hline & & $\begin{array}{l}\text { Central bank is an active participant in the } \\
\text { primary market }\end{array}$ & 0 & \\
\hline \multirow[t]{2}{*}{$\begin{array}{l}\text { 6) Lender of } \\
\text { Last Resort } \\
\text { Function }\end{array}$} & \multirow[t]{2}{*}{$\begin{array}{l}\text { Lender of last } \\
\text { resort function }\end{array}$} & $\begin{array}{l}\text { Central bank provides only emergency } \\
\text { loans to banks, with predetermined limits } \\
\text { (if limits were legally specified, it follows } \\
\text { those limits, otherwise, limits are set prior } \\
\text { application) }\end{array}$ & 1 & \multirow[t]{2}{*}{$\begin{array}{l}\text { Analysing data } \\
\text { on central bank } \\
\text { emergency loans to } \\
\text { banks }\end{array}$} \\
\hline & & $\begin{array}{l}\text { Central bank follows a discretionary policy } \\
\text { for emergency loans }\end{array}$ & 0 & \\
\hline
\end{tabular}

\begin{tabular}{|c|c|c|c|c|}
\hline & \multirow{3}{*}{$\begin{array}{l}\text { Limitations } \\
\text { on securitized } \\
\text { lending }\end{array}$} & $\begin{array}{l}\text { Central bank does not provide } \\
\text { government with securitized Lending }\end{array}$ & 1 & \multirow{3}{*}{$\begin{array}{l}\text { Analysing data } \\
\text { on securitized } \\
\text { lending provided to } \\
\text { government }\end{array}$} \\
\hline & & $\begin{array}{l}\text { Central bank provides government with } \\
\text { securitized lending within the legally } \\
\text { approved limits }\end{array}$ & 0.5 & \\
\hline & & $\begin{array}{l}\text { Central bank provides government with } \\
\text { securitized lending but violates the } \\
\text { legally approved limits }\end{array}$ & 0 & \\
\hline & \multirow{3}{*}{$\begin{array}{l}\text { Limitations on } \\
\text { indirect credit }\end{array}$} & $\begin{array}{l}\text { Central bank does not provide indirect } \\
\text { credit to government. }\end{array}$ & 1 & \multirow{3}{*}{$\begin{array}{l}\text { Analysing data } \\
\text { on indirect credit } \\
\text { provided to } \\
\text { government }\end{array}$} \\
\hline & & $\begin{array}{l}\text { Central bank provide indirect credit within } \\
\text { the legally specified limitations }\end{array}$ & 0.5 & \\
\hline & & $\begin{array}{l}\text { Central bank provide indirect credit, but } \\
\text { violates the legally specified limitations }\end{array}$ & 0 & \\
\hline & \multirow{4}{*}{$\begin{array}{l}\text { Potential } \\
\text { borrowers from } \\
\text { central bank }\end{array}$} & Only central government & 1 & \multirow{4}{*}{$\begin{array}{l}\text { Analysing data on } \\
\text { central bank credit to } \\
\text { various parties }\end{array}$} \\
\hline & & $\begin{array}{l}\text { Central and state government as well as } \\
\text { political subdivisions }\end{array}$ & 0.67 & \\
\hline & & $\begin{array}{l}\text { Central and state government, political } \\
\text { subdivisions and public enterprises }\end{array}$ & 0.33 & \\
\hline & & All the public sector and private sector & 0 & \\
\hline & \multirow{3}{*}{$\begin{array}{l}\text { Maturity of } \\
\text { loans }\end{array}$} & Within 6 months & 1 & \multirow{3}{*}{$\begin{array}{l}\text { Calculating the } \\
\text { maturity of Central } \\
\text { bank loans to } \\
\text { government }\end{array}$} \\
\hline & & Within 1 year & 0.5 & \\
\hline & & More than 1 year & 0 & \\
\hline & \multirow{4}{*}{$\begin{array}{l}\text { Interest rates on } \\
\text { loans }\end{array}$} & Market rates & 1 & \multirow{4}{*}{$\begin{array}{l}\text { Analysing interest rate } \\
\text { on central bank loans } \\
\text { to government }\end{array}$} \\
\hline & & $\begin{array}{l}\text { As legally specified (if legal limits are } \\
\text { different than market rates) }\end{array}$ & 0.67 & \\
\hline & & Violates the legal limits & 0.33 & \\
\hline & & Loans are non-interest bearing & 0 & \\
\hline & \multirow{3}{*}{$\begin{array}{l}\text { Central bank's } \\
\text { participation } \\
\text { in the primary } \\
\text { market for } \\
\text { government } \\
\text { securities }\end{array}$} & $\begin{array}{l}\text { Central bank does not participate in the } \\
\text { primary market for government securities }\end{array}$ & 1 & \multirow{3}{*}{$\begin{array}{l}\text { Analysing data on } \\
\text { market participants in } \\
\text { the primary market for } \\
\text { government securities }\end{array}$} \\
\hline & & $\begin{array}{l}\text { Central bank occasionally participates } \\
\text { in the primary market for government } \\
\text { securities }\end{array}$ & 0.5 & \\
\hline & & $\begin{array}{l}\text { Central bank is an active participant in the } \\
\text { primary market }\end{array}$ & 0 & \\
\hline \multirow[t]{2}{*}{$\begin{array}{l}\text { 6) Lender of } \\
\text { Last Resort } \\
\text { Function }\end{array}$} & \multirow[t]{2}{*}{$\begin{array}{l}\text { Lender of last } \\
\text { resort function }\end{array}$} & $\begin{array}{l}\text { Central bank provides only emergency } \\
\text { loans to banks, with predetermined limits } \\
\text { (if limits were legally specified, it follows } \\
\text { those limits, otherwise, limits are set prior } \\
\text { application) }\end{array}$ & 1 & \multirow[t]{2}{*}{$\begin{array}{l}\text { Analysing data } \\
\text { on central bank } \\
\text { emergency loans to } \\
\text { banks }\end{array}$} \\
\hline & & $\begin{array}{l}\text { Central bank follows a discretionary policy } \\
\text { for emergency loans }\end{array}$ & 0 & \\
\hline
\end{tabular}

\section{6) Lender of Last Resort Function}

Lender of last resort function 


\begin{tabular}{|c|c|c|c|c|}
\hline \multirow{11}{*}{$\begin{array}{l}\text { 7) Financial } \\
\text { Independence }\end{array}$} & \multirow{5}{*}{$\begin{array}{l}\text { Ownership of } \\
\text { central bank } \\
\text { equity capital }\end{array}$} & $\begin{array}{l}\text { Central bank's capital is owned by the } \\
\text { central bank }\end{array}$ & 1 & \multirow{5}{*}{$\begin{array}{l}\text { Analysing data on } \\
\text { central bank equity } \\
\text { capital and main } \\
\text { shareholders }\end{array}$} \\
\hline & & $\begin{array}{l}\text { Government owns less than half of the } \\
\text { central bank capital }\end{array}$ & 0.75 & \\
\hline & & $\begin{array}{l}\text { Government owns more than half of the } \\
\text { central bank capital }\end{array}$ & 0.5 & \\
\hline & & $\begin{array}{l}\text { Government owns all the central bank } \\
\text { capital }\end{array}$ & 0.25 & \\
\hline & & $\begin{array}{l}\text { Private sector owns the central bank } \\
\text { capital }\end{array}$ & 0 & \\
\hline & \multirow{3}{*}{$\begin{array}{l}\text { Who } \\
\text { determines } \\
\text { central bank's } \\
\text { internal budget? }\end{array}$} & $\begin{array}{l}\text { Central bank board alone determines the } \\
\text { internal budget or with the approval of } \\
\text { the legislature or the president }\end{array}$ & 1 & \multirow{3}{*}{$\begin{array}{l}\text { Analysing the practica } \\
\text { procedures for setting } \\
\text { the central bank's } \\
\text { internal budget }\end{array}$} \\
\hline & & $\begin{array}{l}\text { Only the legislature or the president } \\
\text { determines the internal budget of the } \\
\text { central bank }\end{array}$ & 0.5 & \\
\hline & & $\begin{array}{l}\text { Only the executive branch determines the } \\
\text { internal budget of the central bank }\end{array}$ & 0 & \\
\hline & \multirow{3}{*}{$\begin{array}{l}\text { Potential central } \\
\text { bank's loss } \\
\text { coverage }\end{array}$} & $\begin{array}{l}\text { Losses are covered by general reserves, } \\
\text { special reserves, or by revaluation account } \\
\text { and other internal funds }\end{array}$ & 1 & \multirow{3}{*}{$\begin{array}{l}\text { Analysing the financial } \\
\text { statements of the } \\
\text { central bank }\end{array}$} \\
\hline & & $\begin{array}{l}\text { Losses are covered only by general } \\
\text { reserves, and the rest from the state } \\
\text { budget }\end{array}$ & 0.5 & \\
\hline & & $\begin{array}{l}\text { Losses are covered only by the state } \\
\text { budget }\end{array}$ & 0 & \\
\hline \multirow{9}{*}{$\begin{array}{l}\text { 8) } \\
\text { Accountability }\end{array}$} & \multirow{3}{*}{$\begin{array}{l}\text { External } \\
\text { monitoring }\end{array}$} & $\begin{array}{l}\text { Central bank shall appear before the } \\
\text { legislature }\end{array}$ & 1 & \multirow{3}{*}{$\begin{array}{l}\text { Analysing the practica } \\
\text { accountability } \\
\text { procedures }\end{array}$} \\
\hline & & $\begin{array}{l}\text { Central bank shall appear before the } \\
\text { president }\end{array}$ & 0.5 & \\
\hline & & $\begin{array}{l}\text { Central bank shall appear before the } \\
\text { government }\end{array}$ & 0 & \\
\hline & \multirow{3}{*}{$\begin{array}{l}\text { Audit of } \\
\text { financial } \\
\text { statements }\end{array}$} & $\begin{array}{l}\text { Independent external auditor or audit } \\
\text { committee in addition to the auditor- } \\
\text { general of the government audits the } \\
\text { annual financial statement that is in } \\
\text { conformity with international standards }\end{array}$ & 1 & \multirow{3}{*}{$\begin{array}{l}\text { Analysing the financial } \\
\text { statements of the } \\
\text { central bank }\end{array}$} \\
\hline & & $\begin{array}{l}\text { Only the auditor-general of the } \\
\text { government audits the annual financial } \\
\text { statement }\end{array}$ & 0.5 & \\
\hline & & $\begin{array}{l}\text { Annual financial statements are submitted } \\
\text { to the supervisor of the central bank } \\
\text { without external auditing (only internal } \\
\text { audit) }\end{array}$ & 0 & \\
\hline & \multirow{3}{*}{$\begin{array}{l}\text { Disclosure of } \\
\text { the central } \\
\text { bank's financial } \\
\text { statements }\end{array}$} & $\begin{array}{l}\text { Central bank publishes its periodic } \\
\text { financial statements along with more } \\
\text { frequent summary of balance sheet } \\
\text { information }\end{array}$ & 1 & \multirow{3}{*}{$\begin{array}{l}\text { Analysing the financial } \\
\text { statements and } \\
\text { publications of the } \\
\text { central bank }\end{array}$} \\
\hline & & $\begin{array}{l}\text { Central bank publishes its balance sheet } \\
\text { only once a year }\end{array}$ & 0.5 & \\
\hline & & $\begin{array}{l}\text { Central bank does not disclose its financial } \\
\text { statements }\end{array}$ & 0 & \\
\hline
\end{tabular}




\begin{tabular}{|c|c|c|c|c|}
\hline & $\begin{array}{l}\text { Publishing of } \\
\text { reports on }\end{array}$ & $\begin{array}{l}\text { Central bank publishes periodic reports } \\
\text { (annual, semi-annual, monthly) about } \\
\text { monetary variables }\end{array}$ & 1 & Analysing central \\
\hline & $\begin{array}{l}\text { monetary } \\
\text { variables }\end{array}$ & $\begin{array}{l}\text { Central bank publishes only annual } \\
\text { reports }\end{array}$ & 0.5 & $\begin{array}{l}\text { bank's reports on } \\
\text { monetary variables }\end{array}$ \\
\hline & & Central bank does not publish any reports & 0 & \\
\hline & & Central bank publishes inflation reports & 1 & \\
\hline & inflation reports & $\begin{array}{l}\text { Central bank does not publish inflation } \\
\text { reports }\end{array}$ & 0 & bank's inflation reports \\
\hline & $\begin{array}{l}\text { Release of } \\
\text { forward looking } \\
\text { analysis or }\end{array}$ & $\begin{array}{l}\text { Central bank publishes explanatory notes } \\
\text { with figures and numbers, along with } \\
\text { information about the models used in the } \\
\text { analysis }\end{array}$ & 1 & $\begin{array}{l}\text { Analysing central } \\
\text { bank's reports on }\end{array}$ \\
\hline & inflation and & $\begin{array}{l}\text { Central bank publishes summary notes } \\
\text { without figures and numbers }\end{array}$ & 0.5 & $\begin{array}{l}\text { inflation and monetary } \\
\text { forecasts }\end{array}$ \\
\hline 9) Transparency & variables & $\begin{array}{l}\text { Central bank does not publish any } \\
\text { forecasts or forward looking analysis }\end{array}$ & 0 & \\
\hline & & $\begin{array}{l}\text { Central bank publishes its policy changes } \\
\text { along with explanation on the same day } \\
\text { that policy changes }\end{array}$ & 1 & Analysing central \\
\hline & policy changes & $\begin{array}{l}\text { Central bank publishes only its policy } \\
\text { change, without explanation or rationale }\end{array}$ & 0.5 & $\begin{array}{l}\text { concerning policy } \\
\text { changes }\end{array}$ \\
\hline & & $\begin{array}{l}\text { Central bank does not publish its policy } \\
\text { changes to the public }\end{array}$ & 0 & \\
\hline & & $\begin{array}{l}\text { Central bank publishes minutes of the } \\
\text { MPC meetings along with justification for } \\
\text { the committee decision }\end{array}$ & 1 & \\
\hline & $\begin{array}{l}\text { Disclosing } \\
\text { minutes of the } \\
\text { MPC meetings }\end{array}$ & $\begin{array}{l}\text { Central bank publishes minutes of the } \\
\text { MPC meetings without any justification } \\
\text { for the committee decision }\end{array}$ & 0.5 & $\begin{array}{l}\text { Analysing central } \\
\text { bank's press releases } \\
\text { on MPC meetings }\end{array}$ \\
\hline & & $\begin{array}{l}\text { Central bank does not publish minutes of } \\
\text { the MPC meetings }\end{array}$ & 0 & \\
\hline & Who formulates & Only the central bank & 1 & Analysing the \\
\hline Exchange & and implements & Central bank along with the government & 0.5 & central bank and \\
\hline Policy & policy? & Government alone & 0 & $\begin{array}{l}\text { the exchange rate } \\
\text { decisions }\end{array}$ \\
\hline
\end{tabular}

\section{Concluding Remarks}

In an attempt to quantify the degree of CBI, this paper constructs two indices of $\mathrm{CBI}$, de jure and de facto measures. The de jure index exclusively reflects the legal provisions related to CBI. The main caveat for this index is that it only reflects the legal degree of independence and not the actual degree. The second index, however, is designed in a manner that reveals the de facto level of independence, through analysing the practical arrangements related to CBI. The present study is expected to add to the existing literature in various aspects. First, the two proposed measures of CBI are more comprehensive in terms of possible institutional 
arrangements compared to the previous measures. The de jure index incorporates several elements related to $\mathrm{CBI}$ that were not grouped together in a unified index before, like financial independence, limitations related to indirect credit to government, accountability, and transparency. The de facto index comprises most of the existing indicators for measuring actual CBI (turnover ratio, political vulnerability indicator and monetary policy reaction function), in addition to new variables, as the lender of last resort function, independence of central bank board, and financial independence, which were not included in almost all previous studies. Second, the two measures are more rigorous compared to previous measures as they incorporate criteria that could be objectively codified with a minimum degree of value judgment. Third, the two measures are comparable as they incorporate nearly the same aspects of CBI. This would facilitate estimating the divergence between de jure and de facto level of independence for any central bank, which was not possible in most previous studies. Such comparison provides a clear indication about the degree of law enforcement in any country. Besides, it identifies aspects of actual CBI that should be further enhanced to match the legal degree of independence. Finally, a detailed guide for coding the variables of the two measures is presented in the paper to allow replicating measuring the degree of independence of any central bank in futures studies.

Lastly, the study suggests two paths for future research on CBI. First, it would be informative to apply the two proposed measures of CBI on different countries and identify the gap between the legal and effective degree of independence across countries so as to shed some light on practical means to minimize the gap between legal and actual degrees of CBI. Second, it might be interesting to incorporate the actual degree of CBI rather than the legal degree, in econometric models estimating the relationship between $\mathrm{CBI}$ and macroeconomic performance in any country, to identify the importance of CBI. 


\section{References}

1. Alesina, A. \& L. H. Summers (1993). Central Bank Independence and Macroeconomic Performance: Some Comparative Evidence. Journal of Money, Credit and Banking, 25(2), 151-162. Available at: http://www.jstor. org/stable/2077833

2. Anastasiou, A. (2009). Central Bank Independence and Economic Performance. Cyprus Economic Policy Review, 3(1), 123-156. Available at: http://www.ucy.ac.cy/erc/documents/FullTextAnastasiou.pdf

3. Arnone, M., B. J. Laurens, J. Segalotto \& M. Sommer (2007). Central Bank Autonomy: Lessons from Global Trends. IMF, Working Paper 88.

4. Banaian, K. (2008). Measuring Central Bank Independence: Ordering, Raking or Scoring?. St. Cloud State University, Economics Faculty, Working Paper 3.

5. Berger, H. \& J. de Haan (1999). A State within the State: An Event Study on the Bundesbank (1948-1973). Scottish Journal of Political Economy, 46(1), 17-39. doi:10.1111/1467-9485.00118

6. Bezhoska, Anita Angelovska (2017). Central Bank Independence: The Case of the National Bank of the Republic of Macedonia. Journal of Central Banking Theory and Practice, 6(3), 35-65. doi: 10.1515/jcbtp-2017-0020

7. Capie, F., S. Fischer, C. Goodhart \& N. Schnadt (1994). The Future of Central Banking: The Tercentenary Symposium of the Bank of England. Cambridge: Cambridge University Press.

8. Cargill, T. F. (2013). A Critical Assessment of Measures of Central Bank Independence. Economic Inquiry, 51(1), 260-272. doi:10.1111/j.14657295.2011.00427.x

9. Crowe, C. \& E. E. Meade (2008). Central Bank Independence and Transparency: Evolution and Effectiveness. IMF, Working Paper 119.

10. Cukierman, A. (1992). Central Bank Strategy, Credibility and Independence: Theory and Evidence.Cambridge, Massachsetts: MIT Press.

11. Cukierman, A. (2007). De Jure, De Facto and Desired Independence: The Bank of Isreal as a Case Study. In Selected Topics in Israel's Monetary Policy, ed. Nissan Liviatan and Haim Barkai, 3-45. New York: Oxford University Press.

12. Cukierman, A., S. B. Webb \& B. Neyapti (1992). "Measuring the Independence of Central Banks and its Effect on Policy Outcomes". The World Bank Economic Review, 6(3), 353-398. Available at:http://documents. worldbank.org/curated/en/797831468739529187/Measuring-theindependence-of-central-banks-and-its-effect-on-policy-outcomes 
13. Cukierman, A. (2004). Legal, Actual and Desirable Independence: A Case Study of the Bank of Israel. Retrived from: http://www.tau.ac.il/ alexcuk/ pdf/boiactvslegl-4.pdf.

14. Cukierman, A. (2006). Central Bank Independence and Monetary Policy Making Institutions: Past, Present and Future. Central Bank of Chile, Working Papers 360.

15. De Sousa, P. A. B. (2001). Independent and Accountable Central Banks and the European Central Bank. European Integration Online Papers (EIOP), 5(9), 1-24. Available at: http://eiop.or.at/eiop/texte/2001-009a.htm

16. Dincer, N. \& B. Eichengreen (2009). Central Bank Transparency: Causes, Consequences and Updates. National Bureau of Economic Research, Working Paper 14791.

17. Elgie, R. (1998). Democratic Accountability and Central Bank Independence: Historical and Contemporary, National and European Perspectives. West European Politics, 21(3), 53-76. doi: $10.1080 / 01402389808425257$

18. Ewiss, A. (2003). Central Bank Independence and the Efficiency in Managing Monetary Policy: A Comparartive Analysis with Focus on Egypt.Unpublished MSc. Thesis, Faculty of Economics and Political Science, Cairo University, Egypt [in Arabic].

19. Forder, J. (1996). On the Assessment and Implementation of Institutional Remedies. Oxford Economic Papers, 48, 39-51. Available at: https://doi. org/10.1093/oxfordjournals.oep.a028560

20. Forder, J. (2000). Traps in the Measurement of Independence and Accountability of Central Banks. University of Oxford, Department of Economics, Discussion Paper 23.

21. Frankel, J. A. (2010). Monetary Policy in Emerging Markets: A Survey. National Bureau of Economic Research, Working Paper 16125.

22. Gerlach-Kristen, P. (2003). Interest Rate Reaction Functions and the Taylor Rule in the Euro Area. European Central Bank, Working Paper 258.

23. Gisselquist, Rachel M. (2014). Developing and Evaluating Governance Indexes: 10 Questions. Policy Studies, 35(5), 513-531. doi: 10.1080/01442872.2014.946484

24. Grilli, V., D. Masciandaro, G. Tabellini, E. Malinvaud \& M. Pagano (1991). Political and Monetary Institutions and Public Financial Policies in the Industrial Countries. Economic Policy, 6(13), 341-392. doi: 10.2307/1344630

25. Hayo, B. \& C. Hefeker (2002). Reconsidering Central Bank Independence. European Journal of Political Economy, 18, 653-674. Available at: https://doi. org/10.1016/S0176-2680(02)00113-1 
26. Hayo, B. \& S. Voigt (2008). Inflation, Central Bank Independence, and the Legal System. Journal of Institutional and Theoretical Economics, 164(4), 751-777. doi:10.1628/093245608786534578

27. Hueng, C. J. (2012). Central Bank Behavior and Statutory Independence. International Atlantic Economic Journal, 40, 111-126. doi: 10.1007/s11293012-9310-X

28. Issing, O. (2006). Central Bank Independence - Economic and Political Dimension. National Institute Economic Review, 196 , 66-76. doi: 10.1177/0027950106067048

29. Ivanović, Valentina (2014). Financial Independence of Central Bank through the Balance Sheet Prism. Journal of Central Banking Theory and Practice, 3(2), 37-59. doi: 10.2478/jcbtp-2014-0010

30. Jácome, L.I. (2001). Legal Central Bank Independence and Inflation in Latin America during the 1990s. IMF, Working Paper 212.

31. Jácome, L. I. \& F. Vázquez (2005). Any Link between Legal Central Bank Independence and Inflation: Evidence from Latin America and the Caribbean. IMF, Working Paper 75.

32. James, H. (2010). Central Banks: between Internationalization and Domestic Political Control.

33. Kamaly, A. \& N. Farrag (2005). Measuring the Degree of Central Bank Independence in Egypt.

34. Klomp, J. \& J. de Haan (2010). Inflation and Central Bank Independence: A Meta Regression Analysis. Journal of Economic Surveys, 24(4), 593-621. doi: 10.1111/j.1467-6419.2009.00597.x

35. Krušković, Borivoje D. (2017). Exchange Rate and Interest Rate in the Monetary Policy Reaction Function. Journal of Central Banking Theory and Practice, 6(1), 55-86. doi: 10.1515/jcbtp-2017-0004

36. Landström, M. (2013). Determinants and Effects of Central Bank Independence Reforms. Unpiblished Doctoral Thesis, Department of Economics, Umeå School of Business and Economics, Umeå University, Sweden.

37. Lybek, T. (1999a). Central Bank Autonomy, Accountability and Governance: Conceptual Framework.

38. Lybek, T. (1999b). Central Bank Autonomy, and Inflation and Output Performance in the Baltic States, Russia, and Other Countries of the Former Soviet Union, 1995-97. IMF, Working Paper 4.

39. Mishkin, F. S. (1998). Central Banking in a Democratic Society: Implications for Transition Countries. 
40. Naini, Ahmad-Reza Jalali \& Mohammad-Amin Naderian (2016).

Overreaction to Policy Signals, and Central Bank Optimal Communication Policy. Journal of Central Banking Theory and Practice, 5(3), 165-187. doi: $10.1515 /$ jcbtp-2016-0025

41. Obben, J. (2006). Does Central Bank Independence really offera Free Lunch to Countries? Massey University, Department of Applied and International Economics Discussion Paper,06.07.

42. Organization for Economic Co-operation and Development (OECD) (2008). Handbook on Constructing Composite Indicators: Methdology and User Guide. Ispra: OECD publishing.

43. Parkin, M, (2012). Central Bank Laws and Monetary Policy Outcomes: A Three Decade Perspective.

44. Pisha, A. (2011). Eurozone Indices: A New Model for Measuring Central Bank Independence. Bank of Greece, Special Conference Paper 5.

45. Romelli, D. (2015). Three Essays on Central Banking. Unpublished PhD Thesis, ESSEC Business School, Université de Cergy Pontoise.

46. Sánchez-Fung, J. R. (2000). Estimating a Taylor-Type Monetary Policy Reaction Function for the Case of a Small Developing Economy.

47. Sharpe, A. \& B. Andrews (2012). An Assessment of Weighting Methodologies for Composite Indicators: The Case of the Index of Economic Well-Being. Ottawa: Centre for the Study of Living Standards, report no. 10.

48. Smaghi, L. B. (2008). Central Bank Independence in the EU: from Theory to Practice. European Law Journal, 14(4), 446-460. doi: 10.1111/j.14680386.2008.00427.x

49. Wessels, B. (2006). Are African Central Banks Sufficiently Independent for Monetary Convergence?. South African Journal of Economics, 74(2), 230247. doi: 10.1111/j.1813-6982.2006.00060.x

50. Wijnholds, J. O. D. \& L.H. Hoogduin (1994). Central Bank Autonomy: Policy Issues. In A Framework for Monetary Stability, ed. Onno De Beaufort Wijnholds, Sylvester C. W. Eijffinger and Lex H. Hoogduin, 75-95. Amsterdam: Kluwer Academic Publishers. 